\title{
Organic Plant Biostimulants and Fruit Quality-A Review
}

\author{
Mayara Rodrigues ${ }^{1, \dagger}$, João Leonardo Corte Baptistella ${ }^{1,+}+\mathbb{C}$, Daniele Caroline Horz ${ }^{1,+}(\mathbb{C}$, \\ Laura Minatel Bortolato ${ }^{1}$ and Paulo Mazzafera ${ }^{1,2, *(\mathbb{D})}$ \\ 1 Departamento de Produção Vegetal, Escola Superior de Agricultura Luiz de Queiroz, Universidade de São \\ Paulo, CP-9, Piracicaba 13.418-900, Brazil; mayararodrigues.agro@gmail.com (M.R.); \\ joaolcbaptistella@gmail.com (J.L.C.B.); danihorz.dh@gmail.com (D.C.H.); \\ lauraminatelbortolato@usp.br (L.M.B.) \\ 2 Departamento de Biologia Vegetal, Instituto de Biologia, Universidade Estadual de Campinas, Rua Monteiro \\ Lobato, 255, Campinas 13.083-862, Brazil \\ * Correspondence: pmazza@unicamp.br \\ + Author contributed equally to this work.
}

Received: 30 May 2020; Accepted: 2 July 2020; Published: 10 July 2020

\begin{abstract}
Plant biostimulants have been increasingly used in agriculture. Plant biostimulants have been mostly investigated regarding their stress attenuation and only a few reports have brought information on their effects on fruit quality, which is related to appearance, chemical and physical attributes. Due to their organic nature, they have a sustainable appeal, attending the demand of consumers worried about the beneficial effects of healthier foods. This review turns evident the little information available on this matter. As fruits have differentiated metabolism, from pollination to harvest and after-harvesting, it is suggested that further research should focus separately on each stage. Thus, research should aim at quality formation, when the fruits are still attached to the plant, and shelf life extension, after harvesting.
\end{abstract}

Keywords: algae extracts; protein hydrolysates; humic acids; fulvic acids; phytohormone; mode of action; post-harvest; post-harvest technology

\section{Introduction}

The quality of edible fruits is related to physical (weight, firmness and color), chemical (soluble solids content, titratable acidity and $\mathrm{pH}$ ) and nutritional (phenolic content and antioxidant capacity) attributes [1,2] and, ultimately, depends on consumer security and preferences [2,3].

Consumer preference is mainly determined by the appearance of the fruit [4], which is linked to visual aspects such as shape, size, color uniformity, damage marks, maturity degree and weight. Although it is not a confirmation of internal quality, the preservation of visual quality has been the main target of post-harvest technology [4,5]. However, this view is changing because of the growing concern of consumers about the nutritional benefits of fruit consumption and the demand for "functional foods" [5].

It should be noted that quality attributes may vary according to species. For tomatoes, the total soluble solids content is a trait that determines the quality of the product because it is related to its sweetness [6]. For premium grape used to produce red wine, the phenolic content and composition are important attributes as they are directly related to wine quality [7]. One of the important attributes for apple consumers is the red color, which is determined by the concentration of anthocyanins [8].

The quality of the fruit that reaches the consumer depends on agronomic practices, environmental conditions [5,9] and post-harvest technology [10,11]. Depending on the species and cultivars, there are 
specific recommendations regarding fertilization, disease control and water availability. Additionally, under field conditions, crop optimal growth and productivity are linked to light quality and intensity, temperature and water supply. Thus, the selection of cultivars depends on the characteristics of the cultivation sites, which together with crop management may strongly influence quality. These environmental limitations can be partially bypassed by growing plants in greenhouses, where temperature, light and water can be controlled. All these factors will have some influence on fruit quality. However, after harvest, fruits still change quality mainly if they are not properly handled and stored. It is important to keep in mind that after harvesting, fruits are still living plant organs. Dorais and Ehret [9] commented that under adequate storage conditions, there may be an increase in the content of carotenoids and phenolic compounds in fruits. To add to that, they also indicated that processing reduces antioxidant compounds, such as vitamin $C$ and some phenolic compounds, and improves digestive absorption by humans. Shi and Le Maguer [12] explained that the lycopene content is often higher in processed products and that is due to their dissociation from the components of the plant matrix.

Since the appearance and nutritional quality are fundamental for the acceptance of fruit by the consumer, there is a great search for the adoption of new techniques and agricultural inputs to meet this demand. At the same time, farmers seek ways to increase productivity in a sustainable manner, to guarantee security and food quality for the consumer, which in return may represent good profits. Towards these goals, the use of plant biostimulants is among the emerging techniques [5].

Many, if not most, of the reports on plant biostimulants focus on the increase in tolerance against abiotic and biotic stresses, but it has been also shown that they can increase seed germination, improve the initial development of seedlings and soil nutrient absorption and increase plant growth (biomass accumulation) and yield [5,13]. Regarding fruit quality, much less has been done, but the available results indicate that plant biostimulants can improve appearance, size and sometimes shape, and sensory characteristics $[14,15]$.

\section{Plant Biostimulants}

The definition of the term "plant biostimulant" has been a matter of discussion because several compounds, organic and inorganic, from different biological sources or not (synthetic), may have stimulant plant growth, broadening too much the number of compounds and certainly weakening the definition. This was properly discussed by Yakhin et al. [16], who suggested the following definition: "a formulated product of biological origin that improves plant productivity as a consequence of the novel, or emergent properties of the complex of constituents, and not as a sole consequence of the presence of known essential plant nutrients, plant growth regulators, or plant protective compounds". A previous and similar definition was proposed by the European Biostimulant Industry Council [17]: plant biostimulants are products of biological origin, including microorganisms, which when applied to plants or soil (roots) stimulate physiological processes promoting better plant performance, with increased growth, production, greater stress tolerance and increased product quality. Therefore, the definition of plant biostimulants is strongly linked to changes in the physiological functions of plants [18]. In this review, we follow the definition proposed by Yakhin et al. [16].

The origin of plant biostimulants is diverse, being obtained from different organic sources, such as microbial fermentation of animal or vegetable raw materials, humic substances, algae extracts, protein hydrolysates, industrial residues, beneficial fungi $[19,20]$ and rhizobacteria that promote plant growth [21]. Other substances, mainly synthetic and not extracted from organic biological sources, may have stimulating properties but are not yet considered as plant biostimulants [22]. Commercial plant biostimulant products are generally microbial inoculants, humic acids (HA), fulvic acids (FA), protein hydrolysates $(\mathrm{PH})$, amino acids (AA) and algae extracts (AE) $[15,23]$.

AEs are the main plant biostimulants available on the market [23], and the brown algae Ascophyllum nodosum is the most used species, having effects on the growth and yield of many crops, in addition to also 
improving the quality of fruits [7]. Another alga also widely used is Ecklonia maxima, which has also been shown to be effective in improving plant growth and fruit quality [24-26].

Protein hydrolysates (PHs) are also widely used as plant biostimulants in agriculture. Such hydrolysates are complex mixtures of oligo- and polypeptides, and amino acids, which vary in their composition and proportion depending on the protein source and the hydrolysis method [27]. PHs seem to improve plant nutrition and the quality of fruits and vegetables [28].

\section{Plant Biostimulants and Fruit Quality}

Although scarce compared with the amount of reports in the recent literature, several results support the conclusion that plant biostimulants can improve fruit quality. The results vary depending on the nature of the plant biostimulant, its composition, the mode of application and the dose applied [18]. Regarding the plant, the response may vary according to the phenological stage at the time of application, nutritional and health status, the environmental condition and the species itself [18]. Thus, the application of the same plant biostimulant may cause different responses to the same species. Such variation among studies highlights the lack of standardization to evaluate plant biostimulants' effects/efficiency. Consequently, it is important to advise farmers that they must test and define which standards should be followed to obtain the benefit of a particular plant biostimulant.

To simplify the presentation of the results on the effects of plant biostimulants on fruit quality, we have grouped the literature according to the species. Several reports used commercial products that are not pure plant biostimulants but mixtures of one or two plant biostimulants, amended with nutrients, hormones, etc. Table 1 shows the composition of these products. Noncommercial plant biostimulants are cited only in the text.

Table 1. Composition of commercial products listed according the main constituent.

\begin{tabular}{|c|c|c|}
\hline Plant Biostimulant & Composition & References \\
\hline \multicolumn{3}{|c|}{ Based on amino acids } \\
\hline Ergostim ${ }^{\circledR}$ XL & $\begin{array}{c}\text { Two carboxylic acids (N-acetiltiazolidin-4-carboxylic acid } \\
\text { (AATC) } 2.5 \% \text {, triazolidine-carboxylic acid (ATC) } 2 \% \text { ) activate } \\
\text { the metabolism of proline and cysteine in plants, which in turn } \\
\text { increases stress tolerance }\end{array}$ & [2] \\
\hline Benefit ${ }^{\circledR}$ & $\begin{array}{c}\text { Organic carbon, amino acids (glycine, alanine, aspartic acid } \\
\text { and glutamic acid), nucleotides, free enzymatic proteins } \\
\text { and vitamins }\end{array}$ & [29] \\
\hline Megafol $^{\circledR}$ & $\begin{array}{l}\text { Amino acids (proline and tryptophan), glycosides, } \\
\text { polysaccharides, organic nitrogen and organic carbon }\end{array}$ & [29] \\
\hline Radifarm $^{\circledR}$ & $\begin{array}{l}\text { Amino acids (asparagine, arginine and tryptophan), } \\
\text { glycosides, polysaccharides and organic acids }\end{array}$ & [29] \\
\hline Actium ${ }^{\circledR}$ & $\begin{array}{l}\text { Mix of polysaccharides, polypeptides and vitamins }(40 \%) \text {, } \\
\text { potassium oxide }(5 \%) \text { and amino acids }(2 \%)\end{array}$ & [30] \\
\hline \multicolumn{3}{|c|}{ Based on plant extracts } \\
\hline Biozyme $^{\circledR}$ & $\begin{array}{l}\text { Macro and micronutrients combined with hydrolyzed } \\
\text { plant extracts }\end{array}$ & [31] \\
\hline Auxym ${ }^{\circledR}$ & $\begin{array}{c}\text { A complex of natural plant extracts from which the auxin-like } \\
\text { effects are derived from the concentration of biologically active } \\
\text { natural substances such as amino acids, vitamins, enzymes, } \\
\text { phytochelatins, auxins, cytokinins, humic acid, } \\
\text { macro and microelements }\end{array}$ & [32] \\
\hline Vipul $^{\circledR}$ & $\begin{array}{c}\text { Is a commercial formulation of triacontanol which is a long } \\
\text { chain } 30 \text { carbon primary alcohol and occurs in nature as a } \\
\text { natural constituent of bees wax and plant waxes }\end{array}$ & [33] \\
\hline
\end{tabular}


Table 1. Cont.

\begin{tabular}{|c|c|c|}
\hline Plant Biostimulant & Composition & References \\
\hline Sunred ${ }^{\circledR}$ & Plant extracts, methionine, phenylalanine, monosaccharides & $\begin{array}{l}{[34]} \\
{[35]}\end{array}$ \\
\hline \multicolumn{3}{|c|}{ Based on algae extracts } \\
\hline Goëmar BM $86^{\circledR}$ & $\begin{array}{c}\text { Gibberellic acid (GA14) seaweed cream + elements } \\
\text { Molybdenum (Mo) } 0.2 \mathrm{~g} / \mathrm{kg} \\
\text { Boron (B) } 21 \mathrm{~g} / \mathrm{kg} \text { Magnesium }(\mathrm{Mg}) 29 \mathrm{~g} / \mathrm{kg} \\
\text { Sulphur (S) } 38 \mathrm{~g} / \mathrm{kg} \\
\text { Contains auxin, cytokinin and betaine }\end{array}$ & [31] \\
\hline Kelpak $^{\circledR}$ & Liquid seaweed concentrate & [32] \\
\hline Biozyme crop plus ${ }^{\circledR}$ & $\begin{array}{l}\text { Is a commercial formulation of } \mathrm{AE}(A . \text { nodosum }) \text {, enzymes and } \\
\text { protein hydrolysate }\end{array}$ & [33] \\
\hline Citocina spic ${ }^{\circledR}$ & $\begin{array}{l}\text { Gibberellic acid, auxins, cytokinins, algae extract (A. nodosum), } \\
\text { PH and trace elements }\end{array}$ & [33] \\
\hline \multicolumn{3}{|c|}{ Based on humic and fulvic acids } \\
\hline Radicon ${ }^{\circledR}$ & $\begin{array}{l}\text { Humic and fulvic acids, obtained from the compost of worm } \\
\text { (night crawled), containing total organic matter: } 4 \% \text {, humified } \\
\text { organic substance } 90 \% \text { of total organic matter }\end{array}$ & [2] \\
\hline $\operatorname{Viva}^{\circledR}$ & $\begin{array}{l}\text { 33\% organic matter in dry matter, folic acid, vitamins B1, B2, } \\
\text { B6 and PP, inositol and humic acids }\end{array}$ & [29] \\
\hline \multicolumn{3}{|c|}{ Protein hydrolysates from animals and plants } \\
\hline Trainer ${ }^{\circledR}$ & It is derived from $100 \%$ plant protein hydrolysate & $\begin{array}{l}{[25]} \\
{[32]}\end{array}$ \\
\hline \multicolumn{3}{|c|}{ Others } \\
\hline Hendophyt ${ }^{\circledR}$ PS & $\begin{array}{c}60 \% \text { biopolymers of polysaccharides (polyglucosamine- } \\
\text { A low-molecular weight chitosan), } 35 \% \text { containing carbon, } \\
4 \% \text { organic nitrogen, } 0.25 \% \text { boron }\end{array}$ & [2] \\
\hline
\end{tabular}

\subsection{Banana (Musa spp.)}

A plant biostimulant prepared by the degradation of chicken feathers, rich in peptides, amino acids and minerals, was sprayed on the leaves at $5 \%$ or applied on banana roots at $20 \%$ via fertigation. The applications were made 15 days after seedlings transplanting and led to an increase in the content of proteins, amino acids, reducing sugars, phenolics and flavonoids in the ripe fruits. Root application was more effective than foliar spray to induce these changes as well as to induce higher productivity [36].

\subsection{Eggplant (Solanum melongena)}

The application of the AE Göemar BM-86 ${ }^{\circledR}$ (Arysta Lifescience, North America, LLC), prepared with $A$. nodosum, on eggplant caused different responses according to the cultivar and the year of evaluation [37]. In general, there was a significant increase in the levels of soluble sugars and the total antioxidant activity of the skin and pulp in the two years of experimentation; some cultivars had increased levels of $\mathrm{P}, \mathrm{Ca}, \mathrm{Fe}$ and $\mathrm{Zn}$ in the fruit. Anthocyanin increased in the fruit peel, but only in the second year of evaluation.

Muhammed Ali et al. [38] varied the number of applications (0, 1, 2 or 3 times) of a plant biostimulant prepared from garlic bulb in eggplant before and after the transplanting stages and evaluated the morphological and biochemical characteristics. When the extract was applied only once in the pre-transplant and three times after the transplant, there was an increase in soluble sugars content by $188 \%$ and $112 \%$, and the fruit yield was increased by $23.6 \%$ and $15.4 \%$, respectively, in comparison with the control. 


\subsection{Capsicum spp.}

Ertani et al. [39] observed an improvement in the quality of pepper with the application of alfalfa and grape-based plant biostimulants. The plant biostimulants increased the levels of ascorbic acid, chlorogenic acid, p-hydroxybenzoic acid and p-coumaric acid, and also the antioxidant activity in green pepper fruits, while red fruits had a higher capsaicin content. Unlu and Karakurt [40] reported a higher content of carotenoids in pepper after application of humic acids.

Antioxidant activity and yield were higher in two sweet pepper cultivars (Century F1 and Blondy F1) treated with a mixture of four commercial plant biostimulants-Radifarm ${ }^{\circledR}$, Megafol $^{\circledR}$, Viva ${ }^{\circledR}$ and Benefit ${ }^{\circledR}$ (Valagro, Atessa, Chieti, Italy)—Which are composed of amino acids and vitamins [29]. The plant biostimulant Actium ${ }^{\circledR}$ (Grupo Agrotecnología, Alicante, Spain), also composed of vitamins and amino acids, was applied on leaves and fruits of sweet pepper cv. "Palermo", and led to an increase in the contents of phenylalanine, monosaccharides (glucose and fructose) and carotenoids, as well as changing the fruit color [30].

\subsection{Cherry (Prunus avium)}

The application of A. nodosum-based AE in two cherry cultivars (Sweetheart and Skeena), grafted on cv. Gisela 6, resulted in a reduction in the cracking index, and an increase in the width, weight, diameter, $\mathrm{pH}$ and wax of the fruits, although the nutritional characteristics and fruit yield did not change [41].

To improve the adaptation of cherry trees to adverse climatic conditions, Gonçalves et al. [42] tested A. nodosum-based AE, salicylic acid and soy betaine, separately, in a commercial orchard of cv. Staccato. There was an increase in total soluble solids, $\mathrm{pH}$, polyphenols, vitamin $\mathrm{C}$ and antioxidant compounds, and improvement in the color and size of fruits with all products. The levels of total soluble solids and $\mathrm{pH}$ and lower values of acidity were more significantly changed with the application of AE and soy betaine. The color index of fruits, such as the saturation of the color, indicated uniform ripening.

\subsection{Citrus spp.}

Application of yeast extract with subsequent application of gibberellic acid in combination with cytokinin benzyl aminopurine led to an increase in the content of ascorbic acid, and macro- and micronutrients in oranges of Citrus sinensis [43].

In orange orchards, fruit harvest was anticipated in up to seven days with the application of $\mathrm{AE}$ (A. nodosum), in addition to increasing total soluble solids and reducing titratable acidity. Productivity increased by $15 \%$ when the applied rate was $0.30 \%$ [44,45].

$\mathrm{AE}($ A. nodosum) increased the yield of mandarin orange (Citrus reticulata $\mathrm{cv}$. Sunburst and Citrus sinensis cv. Valence) by $11 \%$ [46]. In three consecutive years of foliar spraying, the same plant biostimulant increased the productivity of Citrus sinensis cv. Washington Navel and Citrus paradisi cv. Ruby Red by 10 to $25 \%$, respectively [47]. Although fruit yield increased, their size and weight remained the same, which was considered as positive since a high fruit load reduces fruit size.

\subsection{Apricot (Prunus armeniaca)}

Tarantino et al. [2] sprayed cv. Orange rubis with the commercial plant biostimulants Hendophyt ${ }^{\circledR}$ PS (Iko-Hydro, Rutigliano, Italy), Ergostim ${ }^{\circledR}$ XL (Sumitono Chemical Italia, Milan, Italy) and Radicon $^{\circledR}$ (Fertek, Calvizzano, Italy) (Table 1), composed of polyglucosamine, humic and fulvic acids, and carboxylic acids. Fruit ripening was accelerated, allowing to collect $73 \%$ of the fruits in the first harvest, compared with $43 \%$ of the control treatment. Still, the antioxidative capacity of the fruits increased in the two years of evaluation and fruits of plants sprayed with Ergostim ${ }^{\circledR}$ were wider than the other plant biostimulants and control plants in one of the two years of evaluation. On the other hand, fruit length, thickness, firmness, color, brightness and weight were not changed by plant biostimulants. 
Other studies $[48,49]$ also showed that the application of humic acids via soil or foliar spray interferes positively with the growth, productivity and quality of the fruits of the cv. Canino. Fathy et al. [48] observed greater weight of fruits, firmness, total soluble solids and ratio between BRIX and acidity, thus promoting a better quality of fruits.

\subsection{Kiwi (Actinidia delicious)}

Donno et al. [50] studied the effects of an extract made of agro-industrial residues, rich in peptides, amino acids and hormones (auxins, gibberellins and cytokinins) on two kiwi cultivars (Hayward and Green Light). Weight and ascorbic acid content increased in fruits of both cultivars, but the antioxidant capacity was greater only in the cv. Hayward, indicating that the effect of the plant biostimulant depends on the genotype of the plant.

\subsection{Apple (Malus domestica)}

$\mathrm{AE}$ (A. nodosum), vitamin $\mathrm{B}$ and alfalfa-based $\mathrm{PH}$ applied separately increased the levels of phenolic compounds and the antioxidant potential of the apple cv. Red Jonathan. The improvement in the intensity and homogeneity of the red color was related to increased levels of anthocyanin in the fruit peel [22]. In the same work, the application of a mixture of amino acids (glycine, proline, hydroxyproline, glutamic acid, alanine and arginine) and $\mathrm{Zn}$ reduced by more than $50 \%$ the incidence of "Jonathan spot", the most common physiological disorder in the apple cv. Red Jonathan [22]. Other quality attributes (average fruit weight, total soluble solids, the acidity and firmness of the pulp) were affected by climatic conditions between the years of evaluation but not by the plant biostimulant.

On the other hand, the application of products of different natures (minerals, organominerals) and the plant biostimulant Sunred ${ }^{\circledR}$ (Biochim S.p.a., Medicina, Italy) (composed of plant extracts, methionine, phenylalanine and monosaccharides) in the ripening phase of the apple fruits of the crs. Daiane and Venice did not influence the quality of the fruits [34].

\subsection{Strawberry (Fragaria $\times$ ananassa)}

The red color of the strawberry is an important visual attribute for consumers. Weber et al. [51] evaluated the application of $\mathrm{AE} \mathrm{(A.} \mathrm{nodosum)} \mathrm{and} \mathrm{silicon} \mathrm{in} \mathrm{greenhouse} \mathrm{organic} \mathrm{cultivation} \mathrm{of} \mathrm{the} \mathrm{cv}$. Clery. Treated fruits harvested at the beginning of the season had the highest levels of anthocyanins. In another strawberry cultivar (cv. Elsanta), Soppelsa et al. [52] reported different effects on quality according to the plant biostimulant used. While the application of $\mathrm{AE}$ (A. nodosum) and alfalfa-based $\mathrm{PH}$ increased the concentration of phenolic compounds by up to $20 \%$, the application of chitosan increased pulp firmness, which would benefit the shelf life of the fruit.

Productivity, titratable acidity, color and the contents of total soluble solids and vitamin C in strawberries of the $\mathrm{cv}$. Camarosa were increased with the foliar application of HA. There was also an increase in the leaf content of K, P, Ca and Mg. On the other hand, the fruits of untreated plants showed a higher total antioxidant capacity and a higher ratio between BRIX and acidity. The same cultivar sprayed with salicylic acid showed higher productivity, vitamin C, total soluble sugars, total acidity, total antioxidant capacity, higher leaf contents of $\mathrm{P}$ and $\mathrm{Ca}$ leaf contents and improved the red color of the fruits. Overall, the best doses that resulted in superior performances were $25 \mathrm{mg} \mathrm{L}^{-1}$ of HA and $2 \mathrm{mM}$ of ascorbic acid [53].

\subsection{Pomegranate (Punica granatum)}

The visual aspect is extremely important for the commercialization of pomegranate fruits. Cracked fruits lose value in the fresh market and are destined especially for fruit juices if there is no contamination by fungi [33].

Three commercial plant biostimulants were tested to assess their effect on the quality of pomegranate fruits, Vipul ${ }^{\circledR}$ (Godrej Agrovet Lts., Sachin, India) (triacontanol that occurs in nature as a natural constituent of beeswax and vegetable waxes), Biozyme crop plus ${ }^{\circledR}$ (Biostadt, Mumbai, India) (AE from 
A. nodosum, hydrolyzed enzymes and proteins) and Cytokine spic ${ }^{\circledR}$ (Spic, Chennai, India) (contains gibberellic acid, auxins, cytokinins, AE from A. nodosum, PH and some nutrients) [33]. All plant biostimulants significantly reduced cracking in fruits, with greater efficiency at the highest doses. All plant biostimulants led to longer fruits, with increased diameter, weight and volume. One of the plant biostimulants also improved the color of the fruits. Given the diverse nature of the products, it is difficult to identify whether the observed effects were due to the growth regulators or to the other components. However, the authors speculated that the fruit cracking reduction was the result of the action of auxins, gibberellins and the activity of hydrolytic enzymes acting to increase the elasticity of cell walls [54]. Indeed, studies carried out with gibberellic acid showed that this hormone can interfere in the elasticity of the cell wall [33], influence the size of the fruits [55] and also control the cracking of pomegranate fruits [56].

\subsection{Tomato (Solanum lycopersicum)}

According to Dorais et al. [57], 9 to 20 of the 25 carotenoids found in human blood are found in tomatoes. Since carotenoids have antioxidant properties, an increase in their contents in tomato fruits has been considered a task to improve fruit quality.

The application of three plant biostimulants, $\mathrm{PH}$ derived from legumes (Trainer ${ }^{\circledR}$, Italpollina USA Inc., Anderson, SC, USA), plant extract $\left(\right.$ Auxym $^{\circledR}$, Italpollina USA Inc.) and seaweed (Kelpak ${ }^{\circledR}$, Kelp Products (Pty) Ltd., Cape Town, South Africa), in the tomato cv. Sir Elyan improved some components of the fruit quality [32]. PH promoted an increase in the total soluble solids content, an attribute related to sweetness. Fruits of plants treated with this plant biostimulant had the highest levels of lycopene, which might be related to the highest levels of $\mathrm{K}$ found, due to the involvement of this nutrient in the biosynthesis of carotenoids [36]. Even though the production costs were higher with the application of plant biostimulants, there were net economic benefits [32]. Rouphael et al. [25] observed that the application of the same $\mathrm{PH}$ (Trainer ${ }^{\circledR}$ ) in two concentrations also increased the antioxidant activity, total soluble solids, $\mathrm{K}$ and $\mathrm{Mg}$, and lycopene, thus improving the nutritional quality of the tomato fruits of the cvs. Sir Elyan and Akyra.

Similar results were obtained by Zodape et al. [58] with the foliar application of AE of Kappaphycus alvarezii in tomatoes. There was an increase of more than $20 \%$ in the levels of ascorbic acid, acidity and total soluble solids, in addition to the levels of N, P, K, Mn and $\mathrm{Zn}$ compared with the treatment control. In contrast, the work of Grabowska et al. [14] with two commercial plant biostimulants (Biozyme ${ }^{\circledR}(\mathrm{PH})$ and Goëmar BM $866^{\circledR}$ (Arysta Lifescience, North America, LLC) (not specified AE plus the nutrients $\mathrm{Mg}, \mathrm{S}, \mathrm{B}$ and $\mathrm{Mo}$ )) and a product based on synthetic nitrophenols (Asahi SL ${ }^{\circledR}$ ), and two tomato cultivars ("Esmeralda F1" and "Dual Plus F1") showed an increase in lycopene, but a reduction in other qualitative aspects such as carotenes, ascorbic acid, soluble sugars and total antioxidant activity. The authors highlighted the different responses obtained according to the tomato cultivar and the plant biostimulant used. The application of AE of the species Ulva flexuosa increased yield and improved the chemical quality of the fruits, and the higher the doses, the greater the increases in BRIX, ascorbic acid, lycopene and phenols [59].

By-products and residues from food processing are abundant, cheap and are rich sources of bioactive compounds of great interest to agriculture. Abou Chehade et al. [60] evaluated the effect of extracts prepared with residues from fennel and lemon processing, and grains used by breweries, individually and in combination, on the quality of organic tomatoes. The results were compared with plants treated with humic acid and control plants. The residues promoted the highest levels of nutrients such as $\mathrm{N}$ and $\mathrm{P}$ in the fruits, in addition to an increase in ascorbic acid content. Brewery by-products led to high contents of $\mathrm{Ca}$ and $\mathrm{Na}$ and the combination of the three residue extracts increased the content of $\mathrm{Mn}$. It was suggested that the greater accumulation of nutrients in the tomato fruit of treated plants might be a consequence of an increased root system and/or activation of genes controlling root growth and nutrient absorption. 


\subsection{Grape (Vitis vinifera)}

The antioxidant capacity of phenolics is believed to improve the nutraceutical value of food [39]. Phenolic compounds are extremely important for the quality of wine [6], thus they are important in grapes used for winemaking. AE from A. nodosum is efficient in increasing the biosynthesis of such compounds in grape. Norrie, Branson and Keathley [61] showed that AE improves the yield and quality of grapes. Frioni et al. [7] tested two doses of AE (1.5 and $3.0 \mathrm{~kg} / \mathrm{ha}$ ) and found higher values of phenols in the fruits of treated plants compared with untreated plants. Furthermore, the authors reported increases in the content of anthocyanins, a key component for the appearance and, consequently, the quality of grapes.

An increase in anthocyanin levels was also observed by Deng et al. [35] in the cv. Red Globe with the individual application of the Sunred ${ }^{\circledR}$ plant biostimulant (Biolchim S.p.a., Medicina, Italy) and S-ABA (abscisic acid) isomer before the beginning of fruit ripening. The authors attribute this increase to a higher expression of eleven genes (PAL, CHI, CHS, F3H, F3' H, F3' $5^{\prime} H, A N S, D F R, U F G T, M Y B 1$ and $M Y B 2$ ) and activity of four enzymes (PAL, CHI, DFR and UFGT) involved in anthocyanin biosynthesis.

Another study found an increase in anthocyanins in the cv. Corvina [62] with the application of lupine hydrolysates (Lupinus albus L.) and milk casein, which led to a more intense color, besides the reduction in plant water losses by transpiration. In the same work, there was a significant increase in total soluble solids content with the application of soybean and lupine hydrolysates, and casein.

Productivity and the total soluble solids were also increased in grapes of the cvs. Feteasca Regala and Riesling Italian with the application of humic acids [63].

\section{Sources of Variation in Results with Plant Biostimulants}

The literature shows that there is large variation regarding the results obtained with plant biostimulants and this has been linked to the complexity of the products' composition. The definition of plant biostimulants covers this complexity. According to Yakhin et al. [16], a "plant biostimulant is a formulated product of biological origin that improves plant productivity as a consequence of the novel or emergent properties of the complex of constituents, and not as a sole consequence of the presence of known essential plant nutrients, plant growth regulators, or plant protective compounds".

Three major aspects respond to the complex composition of the available products: (1) the origin of the raw material; (2) the way the raw material is processed; and (3) the presence of other components in the commercialized product.

Taking AE as an example, macroalgae (also known as seaweeds) are predominantly used for processing because of the large biomass they can accumulate. Most products available on the market use brown algae (Phaeophyta), such as Sargassum spp., Ecklonia spp., Laminaria spp., Fucus spp., Durvillaea spp. and Turbinaria spp. $[16,64,65]$. Among several species, A. nodosum is the most used alga for plant biostimulant processing, being also largely used in the food and cosmetics industry [66]. Close to 35 countries, in all continents, exploit the algae market for plant biostimulants [67], which means that algae growth and quality (composition) may be affected by local climatic and sea conditions. It is known that temperature, light [68] and salinity [69-71], among other abiotic growth conditions, may influence the quality of the final product.

$\mathrm{PH}$ suffers from the same problem. The raw material used for $\mathrm{PH}$ production can be proteins from agro-industrial by-products of animal and vegetable origin such as leather, feathers, blood, casein (from milk) viscera, seeds and cultural remains, among others [20,72]. Almost all PHs on the market are predominantly produced from the chemical hydrolysis of proteins of animal origin, such as collagen, or obtained from proteins derived from the leather and fishing industries, without specification of the species used [20]. Very few PHs have proteins of plant origin, the main sources being legume seeds and alfalfa hay [20].

Although using the same raw material, the method used for processing can completely change the efficiency of a plant biostimulant. Boukhari et al. [73] commented that processing is the biggest challenge in the production of algae-based plant biostimulants. The most used procedure is alkaline 
digestion (with $\mathrm{KOH}$ or $\mathrm{NaOH}$ ) associated with pressure, which significantly affects the properties of algae components, such as sugars released from the cell wall, which are chemically broken down [73]. New methods, such as supercritical extraction, have been proposed to minimize chemical changes, but they are still little used mainly due to the cost and low capacity to process large amounts of raw material. For PHs, acidic or basic hydrolysis is usually used for proteins of animal origin, while enzymatic hydrolysis is the preferred method for proteins of plant sources. Whilst acid hydrolysis employs $\mathrm{HCl}$ and a high temperature $\left(>120^{\circ} \mathrm{C}\right)$ and pressure $(>220.6 \mathrm{kPa})$, alkaline hydrolysis is done by initially heating proteins in solution, with the subsequent addition of alkalizing agents, such as $\mathrm{NaOH}$ or $\mathrm{KOH}[74]$.

Several examples in the literature illustrate the variety of responses regarding plant biostimulants used in agriculture. In one of them, two commercial AE products made from $A$. nodosum, processed by two different methods, were applied to the model plant Arabidopsis thaliana. The analysis of the constituents of the two extracts clearly indicated marked differences, even though the seaweed was the same. The transcriptome analysis revealed different profiles as one of the products altered the expression (up- and downregulated) of a much larger number of genes, although growth was similar between AEs and greater than the control [75].

Sharma et al. [76] compared AE from five species (A. nodosum, Fucus serratus, Fuscus vesiculus, Laminaria hyperbolia and Sargassum muticum), collected during summer and winter seasons and processed by three methods (acidic, neutral and alkaline). The authors observed large variation regarding the growth and development of Vigna radiata and Brassica rapa subsp. Chinensis and suggested that this was a consequence of the AE composition, season of collection and method used for processing the extracts.

Another study investigated the effect of three commercial AE on tomato tolerance to water stress [77]. The AEs were produced from A. nodosum and differed in terms of processing method. One was produced under neutral $\mathrm{pH}$ and high temperature, and the other two under alkaline $\mathrm{pH}$ and high temperature. The three AE differed significantly in their composition and although all conferred a degree of tolerance against water stress, the responses were different from each other. The greater efficiency of one of the AEs seemed to be related to the greater accumulation of osmolytes and the greater expression of dehydrins in the plants.

In addition to the variation brought by the raw material source and the processing methods, most of the commercialized plant biostimulants have other components in the formulae, like nutrients, hormones and even a second plant biostimulant source (see Table 1). Besides, some countries do not have specific legislation for these products, as exists in Europe [17]. For instance, in Brazil, the legislation includes plant biostimulants as a category within biofertilizers. Therefore, plant biostimulant products in Brazil are mostly mixtures of nutrients containing components of organic origin, without a clear specification about their nature (only the percentage of carbon is clearly defined). The majority of these products are recommended for foliar application since the added value to liquid fertilizer is much higher than solid fertilizers [78].

In addition to the points raised above, variations exist depending on the plant species treated with plant biostimulants, the stage of development, environmental factors and the mode of application, among others related to crop management. Therefore, in practice, the farmer should test different products before use, and clearly define what the responses are aimed at, i.e., plant growth, productivity, fruit quality, tolerance to stresses, etc.

\section{Mode and Mechanisms of Action of Plant Biostimulants}

In the pharmaceutical research area, the definition of the mode of action is the functional or anatomical change that results from the exposure of a living organism to a substance. Mechanism of action defines these changes at the molecular level [79]. Considering these concepts in published reports on plant biostimulants, it is evident that little is known about their mode and mechanisms of action in plants. In general, the reports show changes in growth and quality of the plant product, 
without addressing functional aspects. Given the anti-stress nature of plant biostimulants, many of these studies show changes in the reactive oxygen substances (ROS) production and related enzyme scavenge activities acting to control oxidative damage. Rare are the works that investigate the way these changes are induced or controlled, and which constituents of the plant biostimulant interact with the plant to stimulate these changes.

In this regard, AEs and PHs are the most studied products. Many of the effects of AE have been attributed to the presence of hormones in the extracts, with special attention to auxins $[15,64,65]$. However, few studies have evaluated the presence and stability of these hormones in formulated products, which seems to be crucial to ascertain any mode or mechanism of action as it is known that, depending on the way the extract is processed and stored, there are significant alterations in the hormone concentration and profile [80]. A recent and comprehensive review provided information on possible mechanisms of action related to the use of $\mathrm{AE}$, mainly based on studies with $A$. thaliana, a model plant for studies in molecular biology, but it also included data on oilseed rape (B. napus), soybean (Glycine max), spinach (Spinacia oleracea), carrot (Daucus carota), tomato (S.lycopersicum) and cucumber (Cucumis sativus) [81]. In general, the review allows concluding that plant biostimulants affect the endogenous balance of hormones, alter the expression of genes related to the transport of nutrients across the cell membrane, stimulate photosynthesis and attenuate stress-related responses. Besides, the review discusses the difficult to separate primary and secondary plant responses. The authors concluded that the wide variation regarding plant biostimulant responses must be linked to the complex composition of AEs. Eventually, the use of functional mutants could better explain the effects of AEs [81].

Ertani et al. [82] used maize (Zea mays) seedlings grown in nutrient solution to study one AE from Laminaria spp. and five from $A$. nodosum and tried to correlate their composition with the observed responses. Seedlings were treated for $48 \mathrm{~h}$ with $0.5 \mathrm{~mL} \mathrm{~L}^{-1}$ single AEs. Spectra obtained with Fourier transformed-infrared (FT-IR) and -Raman (FT-Raman) analysis showed that alginic and uronic acids (FT-IR spectra) and polyaromatic ring compounds (FT-Raman) were the most abundant compounds in the AEs. Hormones and phenolics were also found but varied significantly among AEs. Based on these data, the authors suggested, for example, that the extract which most induced root traits had the highest content of the hormone IAA. However, there was variation among extracts and the authors suggested that the different capacities of AEs to cause responses in maize were probably related to their composition.

Reports on the PH mechanism of action $[20,32,83,84]$ also follow the same arguments and conclusions suggested for AE. Due to the nature of the source of proteins and processing methods, the composition of products containing $\mathrm{PH}$ is quite variable, having a complex mixture of oligo- and polypeptides, and amino acids [27]. Further, in a generic fashion, a recent review on PH concluded that these products affect the metabolism of $\mathrm{C}$ and $\mathrm{N}$, the absorption of nutrients and the hormonal balance [32]. It has also been suggested that application via seed cover could be interfering with the rhizosphere microbiome, with beneficial consequences for plant growth [32].

\section{Bibliometric Analysis}

The literature compiled in this review was integrated by finding the co-occurrence of terms in the title and abstract using VOSViewer, a software for bibliographic analysis and mapping $[85,86]$. The summarized bibliographic analysis went as such: the terms repeated at least five times were selected, the typographical errors were removed, and terms that appeared in both singular and plural forms were standardized to singular forms to avoid redundancies. The same was done for abbreviations and full names, where the latter was chosen. For example, the occurrence of "Ascophyllum nodosum" and "A. nodosum" were both computed together as the former. Based on these premises, 44 terms were used and clustered according to the strength of association between them. Five clusters were generated and integrated into a network overlay visualization map (Figure 1). The size of the circles and font is proportional to the frequency of term occurrence, thus the larger, the greater the frequency; 
the lines represent the linkage among terms, and its thickness represents the relative link strength, thus thicker lines mean stronger relationships among terms. The color bar represents the evolution of the term occurrence according to the year of publication of the study.

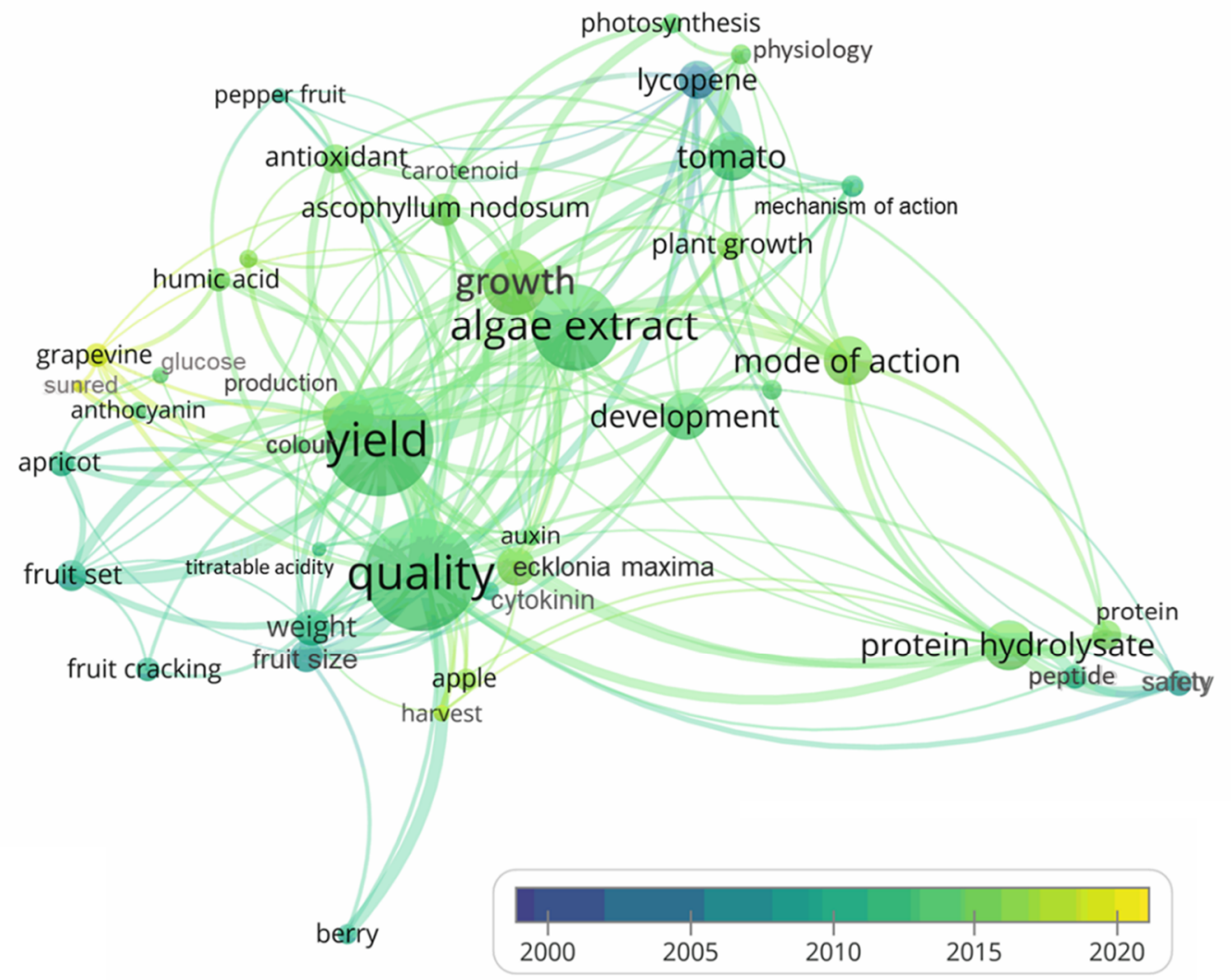

Figure 1. Network of terms found in the literature cited in this review.

As expected, quality and yield are the main terms. "Algae extracts" and "protein hydrolysates" are the main plant biostimulants used in the research concerning fruit quality. "A. nodosum" and "E. maxima "are the algae investigated concerning fruit quality. "Tomato" is the main crop, although "pepper", "grapevine", "apple", "berry" and "apricot" are also displayed. Among fruit attributes, "antioxidant" and "weight" are the main terms. The term "growth" is related to fruit growth and distinguished from "plant growth", thus indicating that it has been a critical trait evaluated in fruit quality. The newest publications were with "grapevine" and "apple", but "mode of action" also appears in the recent literature, indicating an effort to understand how plant biostimulants improve fruit quality. "Auxin" and "cytokinin" have been related to "mode of action". It is also interesting to observe that "mode of action" was more strongly related to "algae extract" than "protein hydrolysate". The "mode of action" of plant biostimulants has been more studied than "mechanism of action". The term "safety" is not strongly linked to "quality", thus indicating a hiatus in the fruit quality $\times$ plant biostimulant research.

\section{Conclusions}

The use of plant biostimulants in agriculture has been increasingly adopted by farmers not only for the positive results but also for being a sustainable alternative. These products are produced from organic material and in many cases from rejects/residues from other industries, as it is the case of most PHs available on the market. This has attracted the attention not only of the farmers but also of a demanding consumer, who accepts to pay more for the nutritional benefits associated with sustainable practices. Plant biostimulants can increase the vigor of plants, and increase the efficiency of nutrients 
and the capacity to tolerate stresses, which ultimately can lead to less chemical fertilizer and pesticides input in crops and better use of water resources.

As shown here, there are many examples that the application of plant biostimulants can improve not only the yield but also the nutritional quality of fruits. Unfortunately, compared with the number of published reports, few have been carried out or focused specifically on fruit quality. Among those, most described the effects of algae and protein hydrolysates extracts, thus indicating a deficiency of knowledge on other plant biostimulants like fulvic and humic acids and of microbial origin. Fruits have a distinguished metabolism in plants (from flower fertilization till harvesting), and as a living organ, metabolic changes continue to happen after harvesting. The length of fruits' commercial shelf-life is primarily based on decreasing metabolic activity by reducing temperature combined or not with changes in the storage atmosphere in an attempt to slow down ripening and senescence [87]. The ability of plant biostimulants to attenuate stresses should be also investigated in fruits as ROS homeostasis may be an important issue to improve shelf-life [88]. We should also consider treating fruits after harvesting. Thus, further studies on the effects of plant biostimulants should consider fruits in the plant as well as treating harvested fruits aiming to unravel the mode and mechanisms of action.

Finally, it is important to highlight that there is an urgent need for further studies with plant biostimulants in perennial crops. The obstacles with these plants are related to the long juvenility period, the need for large experimental areas due to the size of the individuals and the time spent to have the crop history regarding abiotic and biotic stresses over the years [2].

Author Contributions: P.M. designed the work and M.R., J.L.C.B., D.C.H., L.M.B. and P.M. wrote the manuscript. All authors have read and agreed to the published version of the manuscript.

Funding: This research received no external funding.

Acknowledgments: M.R., J.L.C.B., D.C.H. and L.M.B. thank The Brazilian National Council for Scientific and Technological Development (CNPq) and São Paulo Research Foundation (2018/02497-3) for student fellowships, and PM for a research fellowship.

Conflicts of Interest: The authors declare no conflict of interest.

\section{References}

1. Mratinić, E.; Popovski, B.; Milošević, T. Evaluation of apricot fruit quality and correlations between physical and chemical attributes. Czech. J. Food Sci. 2011, 29, 161-170. [CrossRef]

2. Tarantino, A.; Lops, F.; Disciglio, G.; Lopriore, G. Effects of plant biostimulants on fruit set, growth, yield and fruit quality attributes of 'Orange rubis ${ }^{\circledR}$ ' apricot (Prunus armeniaca L.) cultivar in two consecutive years. Sci. Hortic. 2018, 239, 26-34. [CrossRef]

3. Camelo, A.F.L. The quality in fruits and vegetables. In Manual for the Preparation and Sale of Fruits and Vegetables: From Field to Market; Instituto Nacional de Tecnología Agropecuaria Estación Experimental Agropecuaria Balcarce: Balcarce, Argentina, 1981; Volume 12, pp. 87-104.

4. Kyriacou, M.C.; Rouphael, Y. Towards a new definition of quality for fresh fruits and vegetables. Sci. Hortic. 2018, 234, 463-469. [CrossRef]

5. Di Vittori, L.; Mazzoni, L.; Battino, M.; Mezzetti, B. Pre-harvest factors influencing the quality of berries. Sci. Hortic. 2018, 233, 310-322. [CrossRef]

6. Kader, A.A. Postharvest Technology of Horticultural Crops, 3rd ed.; Kader, A.A., Ed.; University of California: Richmond, CA, USA, 2002.

7. Frioni, T.; Sabbatini, P.; Tombesi, S.; Norrie, J.; Poni, S.; Gatti, M.; Palliotti, A. Effects of a biostimulant derived from the brown seaweed Ascophyllum nodosum on ripening dynamics and fruit quality of grapevines. Sci. Hortic. 2018, 232, 97-106. [CrossRef]

8. Ubi, B.E. External stimulation of anthocyanin biosynthesis in apple fruit. Food Agric. Environ. 2004, 2, 65-70.

9. Dorais, M.; Ehret, D.L. Agronomy and the nutritional quality of fruit. In Improving the Health-Promoting Properties of Fruit and Vegetable Products; Woodhead Publishing Limited: Cambridge, UK, 2008; pp. 346-391, ISBN 9781845691844. 
10. Ledbetter, C.; Peterson, S.; Jenner, J. Modification of sugar profiles in California adapted apricots (Prunus armeniaca L.) through breeding with Central Asian germplasm. Euphytica 2006, 148, 251-259. [CrossRef]

11. Ruiz, D.; Egea, J. Phenotypic diversity and relationships of fruit quality traits in apricot (Prunus armeniaca L.) germplasm. Euphytica 2008, 163, 143-158. [CrossRef]

12. Shi, J.; Le Maguer, M. Lycopene in tomatoes: Chemical and physical properties affected by food processing. Crit. Rev. Food Sci. Nutr. 2000, 40, 1-42. [CrossRef]

13. Carvalho, M.E.A.; Castro, P.R.C. Extratos de algas e suas aplicações na agricultura. Série Prod. Rural 2014, 58. [CrossRef]

14. Looney, N.E. Improving Fruit Size, Appearance, and Other Aspects of Fruit Crop "Quality" with Plant Bioregulating Chemicals. Acta Hortic. 1993, 120-127. [CrossRef]

15. Calvo, P.; Nelson, L.; Kloepper, J.W. Agricultural uses of plant biostimulants. Plant. Soil 2014, 383, 3-41. [CrossRef]

16. Yakhin, O.I.; Lubyanov, A.A.; Yakhin, I.A.; Brown, P.H. Biostimulants in plant science: A global perspective. Front. Plant. Sci. 2017, 7. [CrossRef]

17. EBIC European Biostimulant Industry Council. Available online: http://www.biostimulants.eu2013 (accessed on 20 May 2020).

18. Ricci, M.; Tilbury, L.; Daridon, B.; Sukalac, K. General principles to justify plant biostimulant claims. Front. Plant. Sci. 2019, 10, 1-8. [CrossRef] [PubMed]

19. Rouphael, Y.; Franken, P.; Schneider, C.; Schwarz, D.; Giovannetti, M.; Agnolucci, M.; De Pascale, S.; Bonini, P.; Colla, G. Arbuscular mycorrhizal fungi act as biostimulants in horticultural crops. Sci. Hortic. 2015, 196, 91-108. [CrossRef]

20. Nardi, S.; Cardarelli, M.; Ertani, A.; Lucini, L.; Canaguier, R. Protein hydrolysates as biostimulants in horticulture. Sci. Hortic. (Amsterdam) 2015, 196, 28-38.

21. Ruzzi, M.; Aroca, R. Plant growth-promoting rhizobacteria act as biostimulants in horticulture. Sci. Hortic. 2015, 196, 124-134. [CrossRef]

22. Soppelsa, S.; Kelderer, M.; Casera, C.; Bassi, M.; Robatscher, P.; Andreotti, C. Use of biostimulants for organic apple production: Effects on tree growth, yield, and fruit quality at harvest and during storage. Front. Plant. Sci. 2018, 9. [CrossRef]

23. Du Jardin, P. Plant biostimulants: Definition, concept, main categories and regulation. Sci. Hortic. 2015, 196, 3-14. [CrossRef]

24. Rengasamy, K.R.R.; Kulkarni, M.G.; Stirk, W.A.; Van Staden, J. Eckol - A new plant growth stimulant from the brown seaweed Ecklonia maxima. J. Appl. Phycol. 2014, 27, 581-587. [CrossRef]

25. Rouphael, Y.; Colla, G.; Giordano, M.; El-Nakhel, C.; Kyriacou, M.C.; De Pascale, S. Foliar applications of a legume-derived protein hydrolysate elicit dose-dependent increases of growth, leaf mineral composition, yield and fruit quality in two greenhouse tomato cultivars. Sci. Hortic. 2017, 226, 353-360. [CrossRef]

26. Kulkarni, M.G.; Rengasamy, K.R.R.; Pendota, S.C.; Gruz, J.; Plačková, L.; Novák, O.; Doležal, K.; Van Staden, J. Bioactive molecules derived from smoke and seaweed Ecklonia maxima showing phytohormone-like activity in Spinacia oleracea L. N. Biotechnol. 2019, 48, 83-89. [CrossRef] [PubMed]

27. Schaafsma, G. Safety of protein hydrolysates, fractions thereof and bioactive peptides in human nutrition. Eur. J. Clin. Nutr. 2009, 63, 1161-1168. [CrossRef] [PubMed]

28. Parrado, J.; Escudero-Gilete, M.L.; Friaza, V.; García-Martínez, A.; González-Miret, M.L.; Bautista, J.D.; Heredia, F.J. Enzymatic vegetable extract with bio- active components: Influence of fertilizer on the colour and anthocyanins of red grapes. J. Sci. Food Agric. 2007, 87, 2310-2318. [CrossRef]

29. Paradiković, N.; Vinković, T.; Vinković Vrček, I.; Žuntar, I.; Bojić, M.; Medić-Šarić, M. Effect of natural biostimulants on yield and nutritional quality: An example of sweet yellow pepper (Capsicum annuum L.) plants. J. Sci. Food Agric. 2011, 91, 2146-2152. [CrossRef]

30. Barrajón-Catalán, E.; Álvarez-Martínez, F.J.; Borrás, F.; Pérez, D.; Herrero, N.; Ruiz, J.J.; Micol, V. Metabolomic analysis of the effects of a commercial complex biostimulant on pepper crops. Food Chem. 2020, 310, 125818. [CrossRef]

31. Grabowska, A.; Kunicki, K.; Slękara, A.; Kalisz, A.; Jezdinský, A.; Gintro-Wicz, K. The effect of biostimulants on the quality parameters of tomato grown for the processing industry. Agrochimica 2015, 59, 203-217. 
32. Colla, G.; Cardarelli, M.; Bonini, P.; Rouphael, Y. Foliar applications of protein hydrolysate, plant and seaweed extracts increase yield but differentially modulate fruit quality of greenhouse tomato. HortScience 2017, 52, 1214-1220. [CrossRef]

33. Aziz, R.A.; Naira, A.; Moieza, A. Effect of plant biostimulants on fruit cracking and quality attributes of pomegranate cv. Kandhari kabuli. Sci. Res. Essays 2013, 8, 2171-2175. [CrossRef]

34. Fenili, C.L.; Petri, J.L.; Steffens, C.A.; De Martin, M.S.; Do Amarante, C.V.T.; Heinzen, A.S. Alternatives to increase the red color of the peel in 'daiane' and 'venice' apples. Rev. Bras. Frutic. 2019, 41, 1-11. [CrossRef]

35. Deng, Q.; Xia, H.; Lin, L.; Wang, J.; Yuan, L.; Li, K.; Zhang, J.; Lv, X.; Liang, D. SUNRED, a natural extract-based biostimulant, application stimulates anthocyanin production in the skins of grapes. Sci. Rep. 2019, 9, 1-8. [CrossRef] [PubMed]

36. Gurav, R.G.; Jadhav, J.P. A novel source of biofertilizer from feather biomass for banana cultivation. Environ. Sci. Pollut. Res. 2013, 20, 4532-4539. [CrossRef] [PubMed]

37. Pohl, A.; Grabowska, A.; Kalisz, A.; Sȩkara, A. The eggplant yield and fruit composition as affected by genetic factor and biostimulant application. Not. Bot. Horti Agrobot. Cluj-Napoca 2019, 47, 929-938. [CrossRef]

38. Ali, M.; Cheng, Z.H.; Hayat, S.; Ahmad, H.; Ghani, M.I.; Liu, T. Foliar spraying of aqueous garlic bulb extract stimulates growth and antioxidant enzyme activity in eggplant (Solanum melongena L.). J. Integr. Agric. 2019, 18, 1001-1013. [CrossRef]

39. Ertani, A.; Pizzeghello, D.; Francioso, O.; Sambo, P.; Sanchez-Cortes, S.; Nardi, S. Capsicum chinensis L. growth and nutraceutical properties are enhanced by biostimulants in a long-term period: Chemical and metabolomic approaches. Front. Plant. Sci. 2014, 5, 375. [CrossRef] [PubMed]

40. Unlu, H.; Karakurt, Y. Influence of humic acid on the antioxidant compounds in pepper fruit. J. Food Agric. Environ. 2010, 8, 434-438.

41. Correia, S.; Oliveira, I.; Queirós, F.; Ribeiro, C.; Ferreira, L.; Luzio, A.; Silva, A.P.; Gonçalves, B. Preharvest Application of Seaweed Based Biostimulant Reduced Cherry (Prunus Avium L.) Cracking. Procedia Environ. Sci. 2015, 29, 251-252. [CrossRef]

42. Gonçalves, B.; Morais, M.C.; Sequeira, A.; Ribeiro, C.; Guedes, F.; Silva, A.P.; Aires, A. Quality preservation of sweet cherry cv. "Staccato" by using glycine-betaine or Ascophyllum nodosum. Food Chem. 2020, 126713. [CrossRef]

43. Atawia, A.A.R.; El-Desouqi, S.A. Trials for improving fruit set, yield and fruit quality of Washington navel orange by application of some growth regulators and yeast extract as a natural source of phytohormones. Ann. Agric. Sci. 1997, 39, 1613-1632.

44. Fornes, F.; Sánchez-Perales, M.; Guardiola, J.L. Effect of a Seaweed Extract on Citrus Fruit Maturation. Acta Hortic. 1995, 75-82. [CrossRef]

45. Fornes, F.; Sánchez-Perales, M.; Guardiola, J.L. Effect of a seaweed extract on the productivity of "de Nules" clementine mandarin and Navelina orange. Bot. Mar. 2002, 45, 486-489. [CrossRef]

46. Koo, R.C.J. Response of citrus to seaweed-based nutrient sprays. Proceed. Fla. State Hort. Soc. 1988, 101, 26-28.

47. Koo, R.C.J.; Alfred, L. Effects of Seaweed Sprays on Citrus Fruit Production. Proceed. Fla. State Hort. Soc. 1994, 107, 82-85.

48. Fathy, M.A.; Gabr, M.A.; El Shall, S.A. Effect of Humic Acid Treatments on "Canino" Apricot Growth, Yield and Fruit Quality. N. Y. Sci. J. 2010, 3, 109-115.

49. Eissa, F.M.; Fathi, M.A.; El Shall, S.A. Response of peach and apricot seedlings to humic acid treatments under salinity condition. J. Agric. Sci. Mansoura Univ. 2007, 32, 3605-3620.

50. Donno, D.; Beccaro, G.L.; Mellano, M.G.; Canterino, S.; Cerutti, A.K.; Bounous, G. Improving the nutritional value of kiwifruit with the application of agroindustry waste extracts. J. Appl. Bot. Food Qual. 2013, 86, 11-15.

51. Weber, N.; Schmitzer, V.; Jakopic, J.; Stampar, F. First fruit in season: seaweed extract and silicon advance organic strawberry (Fragaria $\times$ ananassa Duch.) fruit formation and yield. Sci. Hortic. 2018, 242, 103-109.

52. Soppelsa, S.; Kelderer, M.; Casera, C.; Bassi, M.; Robatscher, P.; Matteazzi, A.; Andreotti, C. Foliar applications of biostimulants promote growth, yield and fruit quality of strawberry plants grown under nutrient limitation. Agronomy 2019, 9, 483. [CrossRef]

53. Aghaeifard, F.; Babalar, M.; Fallahi, E. Influence of Humic Acid and Salicylic Acid on Yield, Fruit Quality, And Leaf Mineral Elements of Strawberry (Fragaria ananassa Duch.) Cv. Camarosa. J. Plant. Nutr. 2015, 39, 1821-1829. [CrossRef] 
54. Byers, R.E.; Carbaugh, D.H.; Presley, C.N. "Stayman" fruit cracking as affected by surfactants, plant growth regulators, and other chemicals. J. Am. Soc. Hortic. Sci. 1990, 115, 405-411. [CrossRef]

55. Zhang, C.; Whiting, M.D. Improving 'Bing' sweet cherry fruit quality with plant growth regulators. Sci. Hortic. 2011, 127, 341-346. [CrossRef]

56. Lal, S.; Ahmed, N.; Mir, J.I. Effect of different chemicals on fruit cracking in pomegranate under Karewa condition of Kashmir valley. Indian J. Plant. Physiol. 2011, 16, 326-330.

57. Dorais, M.; Papadopoulos, A.P.; Gosselin, A. Greenhouse Tomato Fruit Quality. Hortic. Rev. 2000, $239-319$. [CrossRef]

58. Zodape, S.T.; Gupta, A.; Rawat, U.S.; Chaudhary, D.R.; Eswaran, K.; Chikara, J. Foliar application of seaweed sao as biostimulant for enhancement of yield and quality of tomato (Lycopersicon esculentum Mill.). J. Sci. Ind. Res. 2011, 70, 215-219.

59. Chanthini, K.M.-P.; Stanley-Raja, V.; Thanigaivel, A.; Karthi, S.; Palanikani, R.; Shyam Sundar, N.; Sivanesh, H.; Soranam, R.; Senthil-Nathan, S. Sustainable agronomic strategies for enhancing the yield and nutritional quality of wild tomato, Solanum lycopersicum (L.) var 'Cerasiforme Mill'. Agronomy 2019, 9, 311. [CrossRef]

60. Abou Chehade, L.; Al Chami, Z.; De Pascali, S.A.; Cavoski, I.; Fanizzi, F.P. Biostimulants from food processing by-products: Agronomic, quality and metabolic impacts on organic tomato (Solanum lycopersicum L.). J. Sci. Food Agric. 2018, 98, 1426-1436. [CrossRef]

61. Norrie, J.; Branson, T.; Keathley, P.E. Marine plant extracts impact on grape yield and quality. Acta Hortic. 2002, 594, 315-319. [CrossRef]

62. Boselli, M.; Bahouaoui, M.A.; Lachhab, N.; Sanzani, S.M.; Ferrara, G.; Ippolito, A. Protein hydrolysates effects on grapevine (Vitis vinifera L., cv. Corvina) performance and water stress tolerance. Sci. Hortic. 2019, 258, 108784. [CrossRef]

63. Popescu, G.C.; Popescu, M. Yield, berry quality and physiological response of grapevine to foliar humic acid application. Bragantia 2018, 77, 273-282. [CrossRef]

64. Khan, W.; Rayirath, U.P.; Subramanian, S.; Jithesh, M.N.; Rayorath, P.; Hodges, D.M.; Critchley, A.T.; Craigie, J.S.; Norrie, J.; Prithiviraj, B. Seaweed extracts as biostimulants of plant growth and development. J. Plant Growth Regul. 2009, 28, 386-399. [CrossRef]

65. Craigie, J.S. Seaweed extract stimuli in plant science and agriculture. J. Appl. Phycol. 2011, 23, 371-393. [CrossRef]

66. Michalak, I.; Chojnacka, K.; Saeid, A. Plant Growth Biostimulants, Dietary Feed Supplements and Cosmetics Formulated with Supercritical $\mathrm{CO}_{2}$ Algal Extracts. Molecules 2017, 22, 66. [CrossRef] [PubMed]

67. Buschmann, A.H.; Camus, C.; Infante, J.; Neori, A.; Israel, Á.; Hernández-González, M.C.; Pereda, S.V.; Gomez-Pinchetti, J.L.; Golberg, A.; Tadmor-Shalev, N.; et al. Seaweed production: Overview of the global state of exploitation, farming and emerging research activity. Eur. J. Phycol. 2017, 52, 391-406. [CrossRef]

68. Singh, S.P.; Singh, P. Effect of temperature and light on the growth of algae species: A review. Renew. Sustain. Energy Rev. 2015, 50, 431-444. [CrossRef]

69. Gonçalves, A.; De Figueiredo, D.; Pereira, M. The effects of different salinity concentrations on growth of three freshwater green algae. Fresenius Environ. Bull. 2006, 15, 1382-1386.

70. Nitschke, U.; Karsten, U.; Eggert, A. Physiological performance of the red alga Stylonema alsidii (Stylonematophyceae) under varying salinities. J. Exp. Mar. Biol. Ecol. 2014, 460, 170-176. [CrossRef]

71. Connan, S.; Stengel, D.B. Impacts of ambient salinity and copper on brown algae: 1 . Interactive effects on photosynthesis, growth, and copper accumulation. Aquat. Toxicol. 2011, 104, 94-107. [CrossRef]

72. Halpern, M.; Bar-Tal, A.; Ofek, M.; Minz, D.; Muller, T.; Yermiyahu, U. The Use of Biostimulants for Enhancing Nutrient Uptake; Elsevier Inc.: Amsterdam, The Netherlands, 2015; Volume 130, ISBN 9780128021378.

73. EL Boukhari, M.E.M.; Barakate, M.; Bouhia, Y.; Lyamlouli, K. Trends in Seaweed Extract Based Biostimulants: Manufacturing Process and Beneficial Effect on Soil-Plant Systems. Plants 2020, 9, 359. [CrossRef]

74. Pasupuleti, V.K.; Demain, A.L. Protein hydrolysates in biotechnology. Protein Hydrolysates Biotechnol. 2010, 1-229. [CrossRef]

75. Goñi, O.; Fort, A.; Quille, P.; McKeown, P.C.; Spillane, C.; O'Connell, S. Comparative Transcriptome Analysis of Two Ascophyllum nodosum Extract Biostimulants: Same Seaweed But Different. J. Agric. Food Chem. 2016, 64, 2980-2989. [CrossRef] 
76. Sharma, S.H.S.; Lyons, G.; McRoberts, C.; McCall, D.; Carmichael, E.; Andrews, F.; Swan, R.; McCormack, R.; Mellon, R. Biostimulant activity of brown seaweed species from Strangford Lough: Compositional analyses of polysaccharides and bioassay of extracts using mung bean (Vigno mungo L.) and pak choi (Brassica rapa chinensis L.). J. Appl. Phycol. 2012, 24, 1081-1091. [CrossRef]

77. Goñi, O.; Quille, P.; O'Connell, S. Ascophyllum nodosum extract biostimulants and their role in enhancing tolerance to drought stress in tomato plants. Plant. Physiol. Biochem. 2018, 126, 63-73. [CrossRef] [PubMed]

78. MAPA. Regulation of Law No. 6,894, of December 16, 1980; MAPA-Ministry of Agriculture, Livestock and Supply: Brasília, Brazil, 2004. Available online: http://www.planalto.gov.br/ccivil_03/_ato2011-2014/2014/ decreto/D8384.htm (accessed on 20 May 2020).

79. Grant, R.L.; Combs, A.B.; Acosta, D. Experimental Models for the Investigation of Toxicological Mechanisms. Compr. Toxicol. Second Ed. 2010, 1-14, 203-224.

80. Stirk, W.A.; Tarkowská, D.; Turečová, V.; Strnad, M.; Van Staden, J. Abscisic acid, gibberellins and brassinosteroids in Kelpak ${ }^{\circledR}$, a commercial seaweed extract made from Ecklonia maxima. J. Appl. Phycol. 2014, 26, 561-567. [CrossRef]

81. De Saeger, J.; Van Praet, S.; Vereecke, D.; Park, J.; Jacques, S.; Han, T.; Depuydt, S. Toward the molecular understanding of the action mechanism of Ascophyllum nodosum extracts on plants. J. Appl. Phycol. 2020, 32, 573-597. [CrossRef]

82. Ertani, A.; Francioso, O.; Tinti, A.; Schiavon, M.; Pizzeghello, D.; Nardi, S. Evaluation of seaweed extracts from laminaria and Ascophyllum nodosum spp. As biostimulants in Zea mays L. using a combination of chemical, biochemical and morphological approaches. Front. Plant. Sci. 2018, 9. [CrossRef] [PubMed]

83. Ertani, A.; Schiavon, M.; Nardi, S. Transcriptome-wide identification of differentially expressed genes in Solanum lycopersicon L. In response to an Alfalfa-protein hydrolysate using microarrays. Front. Plant Sci. 2017, 8, 1-19. [CrossRef]

84. Casadesús, A.; Polo, J.; Munné-Bosch, S. Hormonal effects of an enzymatically hydrolyzed animal protein-based biostimulant (pepton) in water-stressed tomato plants. Front. Plant. Sci. 2019, 10, 1-11. [CrossRef]

85. Van Eck, N.J.; Waltman, L. Software survey: VOSviewer, a computer program for bibliometric mapping. Scientometrics 2010, 84, 523-538. [CrossRef]

86. Van Eck, N.J.; Waltman, L. VOSviewer Manual; Univeristeit Leiden: Leiden, The Netherlands, 2013; Volume 1, pp. 1-53.

87. Brizzolara, S.; Manganaris, G.A.; Fotopoulos, V.; Watkins, C.B.; Tonutti, P. Primary Metabolism in Fresh Fruits during Storage. Front. Plant. Sci. 2020, 11, 1-16. [CrossRef]

88. Decros, G.; Baldet, P.; Beauvoit, B.; Stevens, R.; Flandin, A.; Colombié, S.; Gibon, Y.; Pétriacq, P. Get the Balance Right: ROS Homeostasis and Redox Signalling in Fruit. Front. Plant. Sci. 2019, 10. [CrossRef] [PubMed]

(C) 2020 by the authors. Licensee MDPI, Basel, Switzerland. This article is an open access article distributed under the terms and conditions of the Creative Commons Attribution (CC BY) license (http://creativecommons.org/licenses/by/4.0/). 